\title{
Effect of Foliar Application of Plant Nutrients on Growth and Yield of Finger Millet
}

\author{
${\text { B.H. } \text { Reddy }^{1 *} \text {, A.V. Bulbule }}^{2}$, P.N. Gajbhiye ${ }^{2}$ and D.S. Patil ${ }^{1}$ \\ ${ }^{1}$ Department of Soil Science and Agricultural Chemistry, \\ College of Agriculture, Kolhapur, India \\ ${ }^{2} S S \& A C$, Zonal Agricultural Research Station, Kolhapur, India \\ *Corresponding author
}

\section{A B S T R A C T}

\section{Keywords}

Finger millet, Foliar nutrition, Growth,

Yield attributes,

Chlorophyll, Grain

and straw yield

Article Info

Accepted:

20 February 2018

Available Online:

10 March 2018
The present investigation was undertaken at Zonal Agricultural Research Station, Shenda Park, Kolhapur during kharif season of 2016 to study the response of finger millet to foliar nutrition on growth and yield on the Entisols. The experiment was laid out in Randomized block design with three replications and eight treatments of foliar sprays viz., Absolute control, General Recommended Dose of Fertilizers, Water spray, Urea spray @ $2 \%$, DAP spray @2\%, $\mathrm{Ca}\left(\mathrm{NO}_{3}\right)_{2}$ spray @ 2\%, $\mathrm{KNO}_{3}$ spray @2\% and 19:19:19 spray @2\%. The foliar sprays were applied at 30 and 50 DAT. Studies revealed that the growth characters, yield attributes and yields of finger millet differed significantly due to foliar spray treatments of different fertilizers. Amongst the different foliar treatments urea spray @ 2\% had recorded significantly highest values which was at par with 19:19:19 but superior over DAP, $\mathrm{Ca}\left(\mathrm{NO}_{3}\right)_{2}$ and $\mathrm{KNO}_{3}$ sprays applied @ 2\%. The treatment GRDF had recorded significantly highest plant height $(112.27 \mathrm{~cm})$, number of tillers (4.25), chlorophyll content at 60 DAT $\left(1.86 \mathrm{mg} \mathrm{g}^{-1}\right)$, number of fingers (7.67), finger length $(10.48 \mathrm{~cm}), 1000$ grain weight (3.53 g), grain yield (26.47 $\left.\mathrm{q} \mathrm{ha}^{-1}\right)$, straw yields $\left(36.21 \mathrm{q} \mathrm{ha}^{-1}\right)$ and BCR (1.54) over all other foliar spray treatments and absolute control.

\section{Introduction}

Finger Millet (Eleusine coracana L. Gaertn.) is an important sustenance crop originally native to the Ethiopian Highlands and was introduced to India about 4000 years ago (Dida et al., 2008). It ranks third in importance among millets in the country in both area (1.29 million ha) and production (2.19 million tonnes) after sorghum and pearl millet. It is valued in traditional production systems to alleviate malnutrition. The grain of finger millet contains $9.2 \%$ proteins, $1.29 \%$ fat, $76.32 \%$ carbohydrates, $2.2 \%$ minerals, $3.90 \%$ ash and $0.33 \%$ calcium. It also contains iron and phosphorus in substantial amount as well as vitamin ' $A$ ' and ' $B$ ' in small quantities (Upadhyaya et al., 2006).

The productivity of finger millet at national level ranges from 600-1900 $\mathrm{kg} \mathrm{ha}^{-1}$. Considerable scope exists to improve this productivity of the crop as the potential of the crop grown particularly in the mountainous and hilly regions of Maharashtra state remains unexploited since the farmers face several 
constraints. One of the major constraints is that the farmer is unable to fertilize the crop. The fertilizers applied to the crop grown on sloppy terrains are lost as run off losses along with rain water. The situation gets more complicated due to continuous high intensity heavy rains received on hilly slopes during the month of July-August. The period is critical since the crop is transplanted during this period as well as it is in active growth period of the crop. The prevailing conditions of heavy rainfall restraints the resource constraint farmers of hilly and sloppy regions to application of chemical fertilizers. Considering these problems faced by the farmers, attempts were made to study the crop nutrition through foliar application of chemical fertilizers at critical growth stages (of 30 and 50 DAT) of finger millet on the crop response and to growth and nutrition of the crop.

\section{Materials and Methods}

The field experiment was conducted to study the effect of foliar application of plant nutrients on growth and yield of finger millet at Zonal Agricultural Research Station, Shenda Park, Kolhapur $\left(16^{0} 43^{\prime} \mathrm{N}\right.$ latitude, $74^{0} 14$ ' E longitude $574 \mathrm{~m}$ AMSL) during Kharif 2016 on Entisol. The soil of experimental plot was sandy clay loam in texture, neutral in reaction $(\mathrm{pH}$ 7.20), moderate in organic carbon $(0.52 \%)$ low in available nitrogen $\left(210 \mathrm{~kg} \mathrm{ha}^{-1}\right)$, high in available phosphorus (42.5 $\mathrm{kg} \mathrm{ha}^{-1}$ ) and moderate in available potash $\left(190 \mathrm{~kg} \mathrm{ha}^{-1}\right)$. The total rainfall received during the period of field experiment was $1067 \mathrm{~mm}$ in 57 rainy days. The relative humidity during morning and evening ranged between 49 and 83 per cent and between 20 and 84 per cent, respectively. The mean maximum temperature ranged between $27.4^{\circ} \mathrm{C}$ and $40.1^{0} \mathrm{C}$ while the mean minimum temperature ranged between $12.7^{\circ} \mathrm{C}$ and $23.7^{\circ} \mathrm{C}$.
The experiment was laid out in a randomized block design comprising eight treatments with three replications. The finger millet cv. Phule Nachani was transplanted at a spacing of 30 $\mathrm{cm} \times 10 \mathrm{~cm}$. Treatments superimposed were Absolute control (T1), GRDF (T2), Water spray (T3), Urea spray @ $2 \%$ (T4), DAP spray@2\%(T5), $\mathrm{Ca}\left(\mathrm{NO}_{3}\right)_{2}$ spray @2\% (T6), $\mathrm{KNO}_{3}$ spray @ 2\% (T7) and 19:19:19 spray@2\% (T8) foliar sprays were applied at 30 and 50 DAT. Basal dose of FYM @ 5 t $\mathrm{ha}^{-1}$ was applied to all treatments except T1. The general recommended dose consisted of basal dose of fertilizer i.e. $30: 30: 30 \mathrm{~kg} \mathrm{~N}$, $\mathrm{P}_{2} \mathrm{O}_{5}$ and $\mathrm{K}_{2} \mathrm{O}$ per hectare and was applied at the time of transplanting. Remaining half dose of the nitrogen i.e. $30 \mathrm{~kg} \mathrm{ha}^{-1}$ was applied 30 days after transplanting. The source of fertilizer was Urea, SSP and MOP. Foliar application of fertilizers was done @ $2 \%$ at two stages (30 DAT- vegetative growth stage and 50 DAT- pre flowering stage). The sources of fertilizers used for spraying were Urea, DAP, $\mathrm{KNO}_{3}, \quad \mathrm{Ca}\left(\mathrm{NO}_{3}\right)_{2}, \quad$ and 19:19:19.Similarly water spray was also done out at two stages namely 30 and 50 DAT. Other cultural practices and plant protection measures was followed as per the recommended package of practices. At maturity, the observations on ancillary characters were recorded on five randomly selected plants in each plot. The total grain and straw yield were recorded.

\section{Results and Discussion}

\section{Growth and yield attributes of finger millet as influenced by the different treatments}

Data illustrated in Table 1 reveal that the growth and yield contributing characters viz., plant height $(\mathrm{cm})$, number of tillers, chlorophyll content (mg $\left.\mathrm{g}^{-1}\right)$, number of fingers, finger length $(\mathrm{cm})$ and 1000 grain weight (g) were influenced by the different treatments. 
The plant height is indicative of the vigour and growth of plant. Among the different foliar spray treatments, significantly highest plant height $(102.93 \mathrm{~cm})$ was recorded by treatment receiving $2 \%$ urea spray which was at par with $2 \%$ 19:19:19 spray $(101.47 \mathrm{~cm})$. The treatment GRDF recorded significantly the highest plant height $(112.27 \mathrm{~cm})$ which was significantly superior over all other treatments. The highest plant height with GRDF may be due to balanced and increased availability of nutrients to the crop due to fertilizer application. These results are in agreement with the results obtained in maize by Mohan kumar et al., (2015) and Ullasa et al., (2016) where 100 per cent RDF has recorded significantly the highest plant height over foliar treatments. The highest plant height might be due to the better nutrition, which plays a vital role in cell division and growth of the plant. Sharnkumar et al., (2012) reported similar results in sorghum where $2 \%$ urea spray was superior over other foliar treatments.

The highest number of tillers (4.25) was recorded by the treatment GRDF which could be due to better nutrition of crop. The treatment, foliar spray of $2 \%$ urea recorded the highest number of tillers (3.67) followed by $2 \%$ spray of 19:19:19 (3.58) which was on par with each other and significantly superior over all other foliar spray treatments and absolute control (2.17). Similar results were observed by Rahman et al., (2014) for wheat where maximum number of tillers was recorded with $2 \%$ urea spray.

Chlorophyll content in leaves also differed significantly due to different foliar spray treatments. Among the foliar spray treatments, $2 \%$ urea spray has recorded the significantly higher chlorophyll content (1.53 $\mathrm{mg} \mathrm{g}^{-1}$ ) which was on par with $2 \%$ 19:19:19 spray $\left(1.48 \mathrm{mg} \mathrm{g}^{-1}\right)$. The results are in agreement with findings of Rahman et al.,
(2014) who reported the highest chlorophyll content of wheat with $2 \%$ urea spray. However GRDF has recorded the highest leaf chlorophyll content $\left(1.86 \mathrm{mg} \mathrm{g}^{-1}\right)$ which was significantly superior over all foliar treatments.

The yield attributes like number of fingers $\mathrm{ear}^{-1}$, finger length and 1000 grain weight were also in similar trends as growth characters. The significantly highest number of fingers ear $^{-1}$ (7.67), finger length (10.48 $\mathrm{cm})$ and 1000 grain weight $(3.53 \mathrm{~g})$ was recorded with GRDF treatment. Amongst the different foliar sprays, $2 \%$ urea spray has recorded significantly the highest number of fingers (6.92), finger length $(9.14 \mathrm{~cm})$ and 1000 grain weight $(3.23 \mathrm{~g})$ however which were at par with $2 \%$ 19:19:19 spray (Fig. 1).

\section{Yields of finger millet as influenced by the different treatments}

The grain and straw yields of finger millet as influenced by different treatments are presented in Table 2. Foliar spray of fertilizers has resulted in significant yield differences among the treatments. The significantly highest grain $\left(23.59 \mathrm{q} \mathrm{ha}^{-1}\right)$ and straw yield (31.96 q ha ${ }^{-1}$ ) were recorded by 2 $\%$ urea spray which was superior over foliar sprays of DAP, $\mathrm{KNO}_{3}$ and $\mathrm{Ca}\left(\mathrm{NO}_{3}\right)_{2} @ 2 \%$ each and at par with $2 \%$ 19:19:19 foliar spray (23.39 $\mathrm{q} \mathrm{ha}^{-1}, 31.14 \mathrm{q} \mathrm{ha}^{-1}$ grain and straw yield respectively). Treatment GRDF recorded significantly superior yields over all foliar spray treatments. The increased grain and straw yields with GRDF could be due to the supplementation of balanced dose of fertilizers which improved vegetative and yield attributing characters.

The results confirm the findings of Das and Jana (2015) who has reported highest grain yield of chick pea with application of $2 \%$ urea spray over different concentrations of 
19:19:19 foliar spray. Rahman et al., (2014) has also reported similar results for wheat with $2 \%$ urea spray. The highest and lowest harvest index percent were recorded by treatment absolute control (43.62 \%) and GRDF (42.23\%), respectively.

The pores within the leaf cuticles can take up the nutrients like urea, ammonium and nitrate etc. These pores are lined with negatively charged molecules (Stevens, 1994 and Oosterhuis, 2009). Therefore, the uptake of cations such as ammonium is comparatively faster than anions. The uptake of small uncharged molecules like urea is also fast.
Thus absorption of nutrients like urea, ammonium and other positively charged particles are rapid and efficient when applied as foliar spray. While the other anions take very long time for its absorption which results in lower efficiency of absorption. The response of foliar application of urea hence appears to be relatively higher than other sources. Similarly the fertilizer 19:19:19 also contains nitrogen that is uncharged as well as positively charged nitrogen. The source DAP provides relatively lower contents of nitrogen while the $\mathrm{Ca}\left(\mathrm{NO}_{3}\right)_{2}$ and $\mathrm{KNO}_{3}$ sources were providing nitrogen in anionic form.

Fig.1 Effect of different treatments on grain and straw yields of finger millet

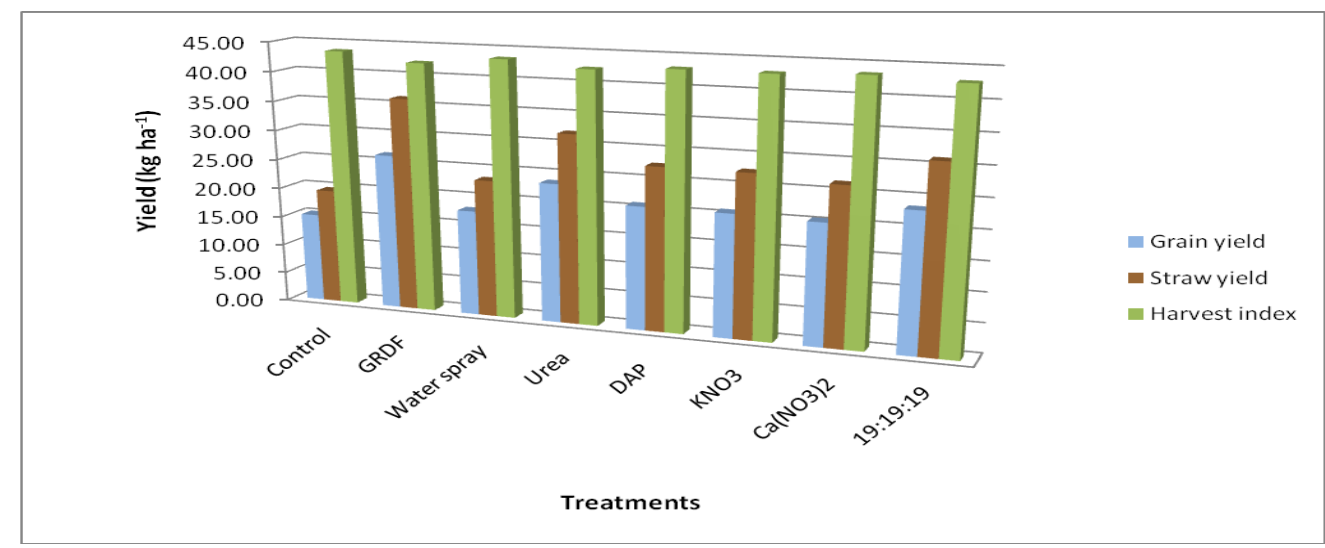

Fig.2 Effect of different treatments on yield attributes of finger millet

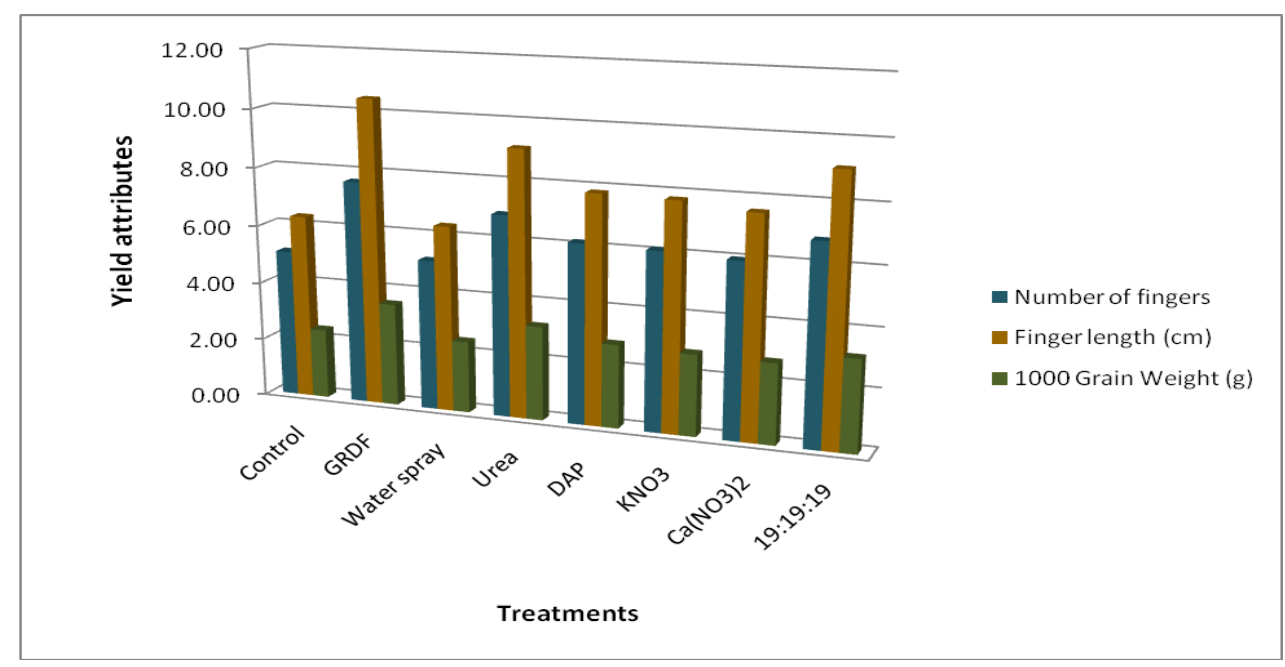


Table.1 Growth and yield attributes of finger millet as influenced by different treatments

\begin{tabular}{|c|c|c|c|}
\hline Treatments & $\begin{array}{l}\text { Grain yield } \\
\qquad\left(\mathrm{q} \mathbf{h a}^{-1}\right)\end{array}$ & $\begin{array}{l}\text { Straw yield } \\
\qquad\left(\mathbf{q} \mathbf{h a}^{-1}\right)\end{array}$ & $\begin{array}{c}\text { Harvest index } \\
(\%)\end{array}$ \\
\hline T1 - Absolute control & 15.19 & 19.64 & 43.62 \\
\hline T2 - GRDF & 26.47 & 36.21 & 42.23 \\
\hline T3 - Water spray & 17.94 & 23.33 & 43.47 \\
\hline T4 - Foliar spray of urea @ 2\% & 23.59 & 31.96 & 42.47 \\
\hline T5 - Foliar spray of DAP @ 2\% & 20.85 & 27.55 & 43.09 \\
\hline T6 - Foliar spray of $\mathrm{KNO}_{3} @ 2 \%$ & 20.77 & 27.50 & 43.03 \\
\hline T7 - Foliar spray of $\mathrm{Ca}\left(\mathrm{NO}_{3}\right)_{2} @ 2 \%$ & 20.42 & 26.55 & 43.48 \\
\hline T8 - Foliar spray of 19:19:19 @ 2\% & 23.39 & 31.14 & 42.89 \\
\hline S. E. \pm & 0.80 & 1.24 & - \\
\hline CD at $5 \%$ & 2.42 & 3.76 & - \\
\hline
\end{tabular}

Table.2 Grain yield, straw yield and harvest index of finger millet as influenced by different treatments

\begin{tabular}{|c|c|c|c|c|c|c|}
\hline Treatments & $\begin{array}{l}\text { Plant } \\
\text { height } \\
(\mathrm{cm})\end{array}$ & $\begin{array}{c}\text { Number } \\
\text { of tillers } \\
\text { plant }^{-1}\end{array}$ & $\begin{array}{c}\text { Chlorophyll } \\
\text { content } \\
\left(\mathrm{mg} \mathrm{g}^{-1}\right) \text { at } 60 \\
\text { DAT }\end{array}$ & $\begin{array}{c}\text { Number } \\
\text { of } \\
\text { fingers } \\
\text { ear }^{-1}\end{array}$ & $\begin{array}{c}\text { Finger } \\
\text { length } \\
(\mathrm{cm})\end{array}$ & $\begin{array}{c}1000 \\
\text { Grain } \\
\text { weight } \\
\text { (g) }\end{array}$ \\
\hline T1 - Absolute control & 75.37 & 2.17 & 0.87 & 5.08 & 6.34 & 2.40 \\
\hline T2 - GRDF & 112.27 & 4.25 & 1.86 & 7.67 & 10.48 & 3.53 \\
\hline T3 - Water spray & 77.18 & 2.25 & 0.88 & 5.17 & 6.38 & 2.47 \\
\hline T4 - Foliar spray of urea @ 2\% & 102.93 & 3.67 & 1.53 & 6.92 & 9.14 & 3.23 \\
\hline T5 - Foliar spray of DAP @ 2\% & 91.83 & 3.08 & 1.19 & 6.17 & 7.85 & 2.87 \\
\hline T6 - Foliar spray of $\mathrm{KNO}_{3} @ 2 \%$ & 88.40 & 2.92 & 1.14 & 6.12 & 7.80 & 2.80 \\
\hline $\begin{array}{c}\mathrm{T} 7 \text { - Foliar spray of } \mathrm{Ca}\left(\mathrm{NO}_{3}\right)_{2} @ \\
\text { @ }\end{array}$ & 86.50 & 2.78 & 1.11 & 6.00 & 7.58 & 2.77 \\
\hline $\begin{array}{c}\text { T8 - Foliar spray of 19:19:19 @ } \\
2 \%\end{array}$ & 101.47 & 3.58 & 1.48 & 6.83 & 9.11 & 3.17 \\
\hline S. E. \pm & 3.02 & 0.14 & 0.06 & 0.19 & 0.36 & 0.09 \\
\hline CD at $5 \%$ & 9.15 & 0.43 & 0.18 & 0.58 & 1.10 & 0.26 \\
\hline
\end{tabular}


Table.3 Economics of finger millet as influenced by different treatments

\begin{tabular}{|c|c|c|c|c|}
\hline Treatments & $\begin{array}{c}\text { Cost of } \\
\text { cultivation } \\
\left(\mathrm{Rs} \mathrm{ha}^{-1}\right)\end{array}$ & $\begin{array}{l}\text { Gross returns } \\
\quad\left(\text { Rs ha }^{-1}\right)\end{array}$ & $\begin{array}{l}\text { Net returns } \\
\left(\text { Rs ha }^{-1}\right)\end{array}$ & $\begin{array}{l}\text { B:C } \\
\text { ratio }\end{array}$ \\
\hline T1 - Absolute control & 31920 & 35404 & 3484 & 1.11 \\
\hline T2 - GRDF & 40202 & 61730 & 21528 & 1.54 \\
\hline T3 - Water spray & 37600 & 41804 & 4204 & 1.11 \\
\hline T4 - Foliar spray of urea @ 2\% & 37720 & 54998 & 17278 & 1.46 \\
\hline T5 - Foliar spray of DAP @ 2\% & 38064 & 48588 & 10524 & 1.28 \\
\hline T6 - Foliar spray of $\mathrm{KNO}_{3} @ 2 \%$ & 38720 & 48386 & 9666 & 1.25 \\
\hline T7 - Foliar spray of $\mathrm{Ca}\left(\mathrm{NO}_{3}\right)_{2} @ 2 \%$ & 39200 & 47587 & 8387 & 1.21 \\
\hline T8 - Foliar spray of 19:19:19 @ 2\% & 40000 & 54486 & 14486 & 1.36 \\
\hline S. E. \pm & - & 1856 & 1856 & - \\
\hline CD at $5 \%$ & - & 5628 & 5628 & - \\
\hline
\end{tabular}

Economics of finger millet as influenced by different treatments

Highest cost of cultivation (Rs.40, $202 \mathrm{ha}^{-1}$ ), gross (Rs. 61,730 ha ${ }^{-1}$ ) and net monetary returns (Rs. 21,528 $\mathrm{ha}^{-1}$ ) and $\mathrm{B}: \mathrm{C}$ ratio (1.54) was recorded with GRDF treatment. Among foliar spray treatments urea has recorded highest gross monetary returns (Rs. 54,998 $\mathrm{ha}^{-1}$ ), net monetary returns (Rs. $17,278 \mathrm{ha}^{-1}$ ) and $\mathrm{B}: \mathrm{C}$ ratio (1.46) followed by 19:19:19 spray (Fig. 2 and Table 3).

In conclusion foliar nutrition at critical growth stages significantly influenced the growth and yields of finger millet. It has the potential to improve the productivity of the crop grown on steep hill slopes where fertilization is a constraint under conditions of heavy rainfall. The growth and yield components were significantly higher with foliar application of $2 \%$ urea followed by 2 $\%$ 19:19:19. Treatments receiving $2 \%$ foliar sprays of DAP, $\mathrm{KNO}_{3}, \mathrm{CaNO}_{3}$ were at par with each other but significantly superior over water spray and control. Foliar spray had positive effect on improving the yield levels of crop. The grain yield was increased by $31.49 \%$ due to the application of urea spray followed by 19:19:19 spray which has recorded $30.37 \%$ increase in yields over water spray treatment.

\section{References}

Das, S. K., and Jana, K. 2015. Effect of foliar spray of water soluble fertilizer at pre flowering stage on yield of pulses. Agric. Sci. Dig., 35(4): 275-279.

Dida, M. M., Wanyera, N., Dunn, M .L. H., Bennetzen, J. L., Devos, K.M. (2008). Population structure and diversity in finger millet (Eleusine coracana) germplasm. Trop. Plant Biol., 1, 131141.

Kuttimani, R. and Velayutham, A. 2011a. Foliar application of nutrients and growth regulators on yield and 
economics of greengram. Madras Agric. J., 98(4):141-143.

Mohan Kumar, R., Hiremath, S. M. and Nadagouda, B. T. 2015. Effect of single-cross hybrids, plant population and fertility levels on productivity and economics of maize (Zea mays). Indian J. Agron. 60 (3): 431-435.

Mudalagiriyappa, Sameer Ali M. , Ramachandrappa B. K., Nagaraju and Shankaralingappa, B. C. 2016. Effect of foliar application of water soluble fertilizers on growth, yield and economics of chickpea (Cicer arietinum L.). Legume Res., 39 (4): 610-613.

Oosterhuis, D. 2009. Foliar fertilization: mechanisms and magnitude of nutrient uptake. In Proceedings of the fluid forum (pp. 15-17).

Rahman, M. Z., Islam, M. R., Karim, M. A. and Islam, M. T. 2014. Response of wheat to foliar application of urea fertilizer. J. Sylhet Agril. Univ., 1(1):39-43.
Sharnkumar, Merwade, Vishalkumar and Gnyandev. 2012. Effect of foliar application of plant nutrients on crop growth, flowering parameters and seed yield on sorghum hybrid cv. SHD9704 (Sorghum bicolor), Internat. J. Forestry Crop Improv., 3 (2) : 86-91.

Stevens, P. J. G. 1994. Formulation of sprays to improve the efficacy of foliar fertilisers. New Zealand Journal of Forestry Science 24(1): 27-34.

Ullasa, M.Y. , Girijesh, G.K. and Dinesh Kumar, M. 2016. Effect of fertilizer levels and foliar nutrition on yield, nutrient uptake and economics of maize (Zea mays L.). Green Farming., 7 (6) : 1383-1388.

Upadhyaya, H.D., Gowda, C.L.L., Pundir, R.P.S., Reddy, V. G., Singh, S. 2006. Development of Core Subset of Finger Millet Germplasm Using Geographical Origin and Data on 14 Quantitative Traits. Genet Resour Crop Evol. 53(4): 679-685.

\section{How to cite this article:}

Reddy, B.H., A.V. Bulbule, P.N. Gajbhiye and Patil, D.S. 2018. Effect of Foliar Application of Plant Nutrients on Growth and Yield of Finger Millet. Int.J.Curr.Microbiol.App.Sci. 7(03): 2203-2209. doi: https://doi.org/10.20546/ijcmas.2018.703.260 